\title{
Comparative Study of the Effect of Ethanol Extract of Psidium Guajava Linn Leaves with Glibenclamide on Experimentally Induced Diabetes Mellitus in Rats
}

\author{
Azmary Momtaz ${ }^{1}$, Khaleda Sharmin ${ }^{2}$, Sharmin Rahman ${ }^{3}$, Nashid Sultana ${ }^{4}$, Rayhana Sharmin ${ }^{5}$
}

\begin{abstract}
Background: Diabetes Mellitus is a major health problem not only in urban but also in the rural areas of Bangladesh. Regarding its treatment, a suitable drug is yet to be available which can permanently cure this disease. Over 400 traditional plants have been reported for the treatment of diabetes, but only a small number have received scientific and medical evaluation to assess their efficacy. Objective: The study was performed to compare the anti diabetic effect of Psidium guajava Linn leaves with an oral anti diabetic drug (Glibenclamide), in experimentally induced diabetic rats. Materials and method: The experiment was carried out in the department of Pharmacology \& Therapeutics of Dhaka Medical College, Dhaka, Bangladesh from July 2012 to June 2013. Twenty four healthy rats of Long Evans Norwegian strain were divided into 4 groups (group A, B, C and D) comprising 6 rats in each. Group A (normal control) received standard rat food for 14 days. Diabetes was induced by administration of Alloxan $120 \mathrm{mg} / \mathrm{kg} /$ body weight in group B, C and D. Group B (diabetic control group) was given standard rat food. Group $C$ and $D$ was treated with ethanol extract of Psidium guajava leaves $100 \mathrm{mg} / \mathrm{kg}$ body weight and Glibenclamide $1.5 \mathrm{mg} / \mathrm{kg} /$ day orally respectively. Total duration of the experiment was 15 days. Results: Administration of ethanol extract of Psidium guajava leaves in group $C$ and Glibenclamide in group D produced a significant reduction $(p<0.001)$ in blood glucose level as compared to group B (diabetic control group). Conclusion: Ethanol extract of Psidium guajava leaves can be considered as a potential anti diabetic agent like Glibenclamide but it requires further investigations.
\end{abstract}

Keywords: Diabetes mellitus; Psidium guajava; alloxan; blood glucose.

$$
\text { Delta Med Col J. Jan 2017;5(1):9 - } 14
$$

\section{Introduction}

Now a days type $2 \mathrm{DM}$ is one of the major public health concerns in both developing and developed countries in Asian-Pacific region. It has become epidemic in a number of countries, particularly in newly industrialized nations. The direct and indirect, social and economic costs of treating

1. Assistant Professor, Dept. of Pharmacology and Therapeutics, Delta Medical College, Dhaka, Bangladesh.

2. Assistant Professor, Dept. of Pharmacology and Therapeutics, University Dental College, Dhaka, Bangladesh.

3. Assistant Professor, Dept.of Pharmacology and Therapeutics, Ibrahim Medical College, Dhaka, Bangladesh.

4. Assistant Professor, Dept. of Pharmacology and Therapeutics, Delta Medical College, Dhaka, Bangladesh.

5. Lecturer, Dept. of Pharmacology and Therapeutics, Uttara Adhunic Medical College, Dhaka, Bangladesh.

Correspondence: Dr. Azmary Momtaz. email: lizasomc@yahoo.com 
diabetes and its complications have the potential to cripple the countries' healthcare budget. In recent times, a new dimension has been added with the increasing appearance of type 2 diabetes in adolescents and even in children. ${ }^{1}$

Excess mortality attributable to diabetes in the year 2000 was estimated to be 2.9 million deaths, equivalent to $5.2 \%$ of all deaths. It accounted for $2-3 \%$ of deaths in poorest countries and over $8 \%$ in the U.S., Canada and Middle East. In people between the age of 35-64 years old, 6-27\% of deaths were attributable to diabetes. ${ }^{2}$

In Bangladesh, the magnitude of diabetes mellitus is increasing. Findings of 10 screening studies carried out from 1996 to 2003 has shown that in mid $60 \mathrm{~s}$, the prevalence of diabetes mellitus was around $1.5 \%$ which has increased to more than $15 \%$ in recent years, (where blood glucose $>7.8$ $\mathrm{mmol} / \mathrm{L}$ after 2 hours of 75 gram glucose was considered as an impaired glucose tolerance). ${ }^{3}$

Traditional medicine derived from medicinal plants is used by about $60 \%$ of the world's population. The World Health Organization has listed 21000 plants, which are used for medicinal purposes around the world. Among these 2500 species are in India. Out of which 150 species are used commercially on a fairly large scale. A list of medicinal plants with proven anti diabetic and related beneficial effects and of herbal drugs in the treatment of diabetes is compiled. This includes Allium sativum, Eugenia jambolana, Momordica charantia, Ocimum sanctum, Phyllantus amarus, Pterocaprus marsupium, Tinospora cordifolia, Trigonella foenum graecum and Withania somniferum. ${ }^{4}$

Psidium guajava is popularly known as guava and has been used traditionally as a medicinal plant throughout the world for a number of ailments. Guava tree is basically from Meso American area. It can also be found in tropical and subtropical areas. Guava tree is a member of myrtaceae family. All the parts of this tree are widely used in curing many health problems. A lot of pharmacological researches have been done to demonstrate the use of extract from guava leaves which proved that it is a very useful medicine, widely used by doctors and pharmacists. The main constituents of guava leaves are phenolic compounds, isoflavonoid, gallic acid, catechin, epicatechin, rutin, naringenin, and kaempferol. 5,6

World health organization (WHO) also says that plants would be the best source of obtaining different types of medicines and drugs. These natural products are widely used by human for its effective results.

The leaves of guava are rich in flavonoids, in particular, quercetin. Quercetin is the main flavonoid in guava leaves which contribute to its anti hyperglycemic effect. Guava leaves also have antioxidant properties which is attributed to the polyphenols found within. ${ }^{7}$

It has also been demonstrated that flavonoids of guava leaves can act as insulin secretagogues or insulin mimetics, probably by influencing the pleiotropic mechanism, attenuate the diabetic complications, and also stimulate glucose uptake in peripheral tissues, and regulate the activity and/or expression of the rate-limiting enzymes involved in carbohydrate metabolism pathway. In a study it was found that flavonoids act directly on pancreatic beta cells leading to activation of the cAMP/PKA signaling cascade to exert an insulinotropic effect. ${ }^{8}$

Glibenclamide (INN), also known as glyburide (USAN), is an anti diabetic drug in a class of medications known as sulfonylureas, closely related to sulfa drugs. It is used in the treatment of type 2 diabetes. The drug works by inhibiting ATP-sensitive potassium channels in pancreatic bets cells. This inhibition causes cell membrane depolarization opening voltage-dependent calcium channel. This results in an increase in intracellular 
calcium in the beta cell and subsequent stimulation of insulin release. ${ }^{9}$

A retrospective study showed that in type 2 diabetic patients already taking glyburide, $\mathrm{NH}$ stroke scale scores were improved on discharge compared to diabetic patients not taking glyburide. ${ }^{10}$

With this background information, in this study, attempt has been taken to make comparison of blood glucose lowering effect of Psidium guajava leaves with an oral anti diabetic drug, Glibenclamide in experimental diabetic rats. Alloxan has been chosen to induce diabetes mellitus in rats. Blood glucose level has been estimated to the extent of pancreatic damage.

\section{Materials and method}

This experimental study has been performed in the department of Pharmacology \& Therapeutics at Dhaka medical college, Dhaka, Bangladesh from July 2012 to June 2013.

A total number of 24 healthy rats of Long Evans Norwegian strain weighing between 140-150 gm and age between 8-10 weeks which were purchased from Bangladesh Centre for Scientific and Industrial Research (BCSIR) Lab were used for the present study. The rats were allowed to live at room temperature with 12 hours of light and 12 hours dark schedule. They were fed normal rat diet and given water ad libitum.

The rats were divided into 4 groups (A, B, C and D). Each group consisted of 6 rats.

\section{Plant materials}

Psidium guajava leaves were collected from local garden. Leaves were dried under shade at room temperature less than 40 degree Celsius.

\section{Preparation of extract}

Ethanol extract was made in the Drug Research
Laboratory of Center for Advanced Research of Sciences (CARS) of Dhaka University. One kg of Psidium guajava (Guava) leaves were cleaned and shade dried. Then it was crushed into coarse powder and soaked in absolute ethanol (2L) with continuous shaking $(40 \mathrm{rmp})$ at $25^{\circ} \mathrm{C}$ for three days and filtered by filter paper. The ethanol extract was evaporated under vacuum rotator evaporator at $35^{\circ} \mathrm{C}$ temperature to obtain final deep green semisolid extract. A total of 30 gram extract was found in this way.

\section{Experimental design}

It is comprised of 24 rats which were divided into 4 groups (Group A, B, C and D) having 6 rats in each. All the rats were fasted overnight before collection of blood.

Group A (Control group) received standard rat food for 14 days. Fasting blood glucose was estimated on day 1, 4 and day 15.

Group B (Diabetic control group) was given alloxan $120 \mathrm{mg} / \mathrm{kg}$ intraperitonially for induction of diabetes on day 1. After alloxan injection rats were given standard food. Fasting blood glucose level were estimated on day 1 (before alloxan), on day 4 on day 15 of the experiment.

Group C was given alloxan $120 \mathrm{mg} / \mathrm{kg}$ intraperitoneally on day 1 . After alloxan injection rats were given standard food. Then after 3 days ethanol extract of Psidiam guajava (guava) leaves $100 \mathrm{mg} / \mathrm{kg} /$ day was given orally along with standard food for 10 days. Fasting blood glucose level was estimated on day 1 (before alloxan), on day 4 and on day 15 of the experiment.

Group D was given alloxan $120 \mathrm{mg} / \mathrm{kg}$ intraperitoneally on day 1. After alloxan injection rats were given standard food. Then after 3 days, Glibenclamide $1.5 \mathrm{mg} / \mathrm{kg} /$ day was given orally along with standard food for 10 days. ${ }^{9}$ Fasting blood glucose was estimated on day 1 (before alloxan), on day 4 and on day 15 of the experiment. 


\section{Results}

Effect of Alloxan on fasting blood glucose (FBG) level of Group B in comparison to group A on day 1,4 and 15

In group $\mathrm{A}$, the blood glucose levels (mean $\pm \mathrm{SD}$ ) in $\mathrm{mmol} / \mathrm{L}$ were $5.80 \pm 0.51,5.80 \pm 0.49$ and $5.80 \pm 0.52$ on day 1, day 4 and day 15 respectively. Percentage change on day 15 from day 1 was 2.30 .

In group $\mathrm{B}$, the blood glucose levels (mean $\pm \mathrm{SD}$ ) in $\mathrm{mmol} / \mathrm{L} \quad$ were $5.70 \pm 0.39, \quad 15.00 \pm 3.35$ and $16.00 \pm 2.85$ on day 1 , day 4 and day 15 respectively. Percentage change on day 4 and day 15 was 170.85 and 190.38 respectively from day 1. The results are shown in Table I.

Table I: Effect of Alloxan on blood glucose level on day 1 , day 4 and day 15

\begin{tabular}{cccc}
\hline Group & \multicolumn{3}{c}{$\begin{array}{c}\text { FBG }(\text { mmol/L) } \\
\text { (Mean } \pm \text { SD) }\end{array}$} \\
& Day 1 & Day 4 & Day 15 \\
\hline A $(\mathrm{n}=6)$ & $5.80 \pm 0.51$ & $5.80 \pm 0.49$ & $5.80 \pm 0.52$ \\
B $(\mathrm{n}=6)$ & $5.70 \pm 0.39 \mathrm{~ns}$ & $15.00 \pm 3.35 * * *$ & $16.00 \pm 2.85 * * *$ \\
\hline
\end{tabular}

$\mathrm{ns}=$ not significant $(\mathrm{p}<0.05)$

$* * *=$ significant at $\mathrm{p}<0.001$

Comparison of FBG level on day 1, day 4 and day 15 with control (group A) done by unpaired student's 't' test.

Effects of Alloxan, Ethanol extract of Psidium guajava (EEPG) leaves, and Glibenclamide on blood glucose level of group B, group C and Group D rats on day 1 , day 4 and day 15

In group $\mathrm{B}$, blood glucose levels (mean $\pm \mathrm{SD}$ ) in $\mathrm{mmol} / \mathrm{L} \quad$ were $5.70 \pm 0.39, \quad 15.00 \pm 3.35$ and $16.00 \pm 2.85$ on day 1 , day 4 and day 15 respectively. Percentage change on day 4 and day 15 was 170.85 and 190.38 respectively from day 1 .

In group $\mathrm{C}$, blood glucose levels (mean $\pm \mathrm{SD}$ ) in $\mathrm{mmol} / \mathrm{L} \quad$ were $5.40 \pm 0.65, \quad 15.35 \pm 4.55$ and $8.60 \pm 2.25$ on day 1 , day 4 and day 15 respectively. Percentage change on day 4 and day 15 was 160.74 and 43.55 respectively from day 1 .
In group D blood glucose levels (mean $\pm \mathrm{SD}$ ) in $\mathrm{mmol} / \mathrm{L} \quad$ were $5.80 \pm 0.48, \quad 15.01 \pm 3.39$ and $7.05 \pm 0.90$ on day 1 , day 4 and day 15 respectively. Percentage change on day 4 and day 15 was 152.45 and 28.86 respectively from day 1 .

Table II: Effect of EESG leaves and Glibenclamaide on blood glucose level in diabetic rats

\begin{tabular}{|c|c|c|c|}
\hline \multirow[t]{2}{*}{ Group } & \multicolumn{2}{|c|}{$\begin{array}{c}\text { FBG }(\mathbf{m m o l} / \mathbf{L}) \\
(\text { Mean } \pm \text { SD })\end{array}$} & \multirow[b]{2}{*}{ Day 15} \\
\hline & Day 1 & Day 4 & \\
\hline $\begin{array}{l}\text { B (Alloxan treated) } \\
(\mathrm{n}=6)\end{array}$ & $5.70 \pm 0.39$ & $15.00 \pm 3.35$ & $16.00 \pm 2.85$ \\
\hline $\begin{array}{l}\mathrm{C}(\text { Alloxan +EEPG leaves treated }) \\
(\mathrm{n}=6)\end{array}$ & $5.40 \pm 0.65 \mathrm{~ns}$ & $15.35 \pm 4.55 \mathrm{~ns}$ & $8.60 \pm 2.25^{* * *}$ \\
\hline $\begin{array}{l}\mathrm{D}(\text { Alloxan+Glibenclamide treated }) \\
(\mathrm{n}=6)\end{array}$ & $5.80 \pm 0.48 \mathrm{~ns}$ & $15.01 \pm 3.39 \mathrm{~ns}$ & $7.05 \pm 0.90^{* * *}$ \\
\hline
\end{tabular}

Percentage change of blood glucose level in diabetic rats after EEPG leaves and Glibenclamide treatment

In group $\mathrm{B}$, the blood glucose levels (mean $\pm \mathrm{SD}$ ) in $\mathrm{mmol} / \mathrm{L}$ were $5.70 \pm 0.39$ and $16.00 \pm 2.85$ on day 1 and day 15 respectively. Percentage change was $190.38 \%$.

In group $\mathrm{C}$, the blood glucose levels (mean $\pm \mathrm{SD}$ ) in $\mathrm{mmol} / \mathrm{L}$ were $5.40 \pm 0.65$ and $8.60 \pm 2.25$ on day 1 and day 15 respectively. Percentage change was $43.55 \%$.

In group $\mathrm{D}$, the blood glucose levels (mean $\pm \mathrm{SD}$ ) in $\mathrm{mmol} / \mathrm{L}$ were $5.80 \pm 0.48$ and $7.05 \pm 0.90$ on day 1 and day 15 respectively. Percentage change was $28.86 \%$.

Unpaired Student's ' $t$ ' test was done between group B and group C and between group B and group D. Differences on day 15 were statistically significant $(\mathrm{p}<0.001)$ (Table-III).

Table III: Effect of EESG (ethanol extract of Psidium guajava) leaves and Glibenclamaide on blood glucose level in diabetic rats with the percentage changes

\begin{tabular}{|c|c|c|c|}
\hline \multirow[t]{2}{*}{ Group } & \multicolumn{2}{|c|}{$\begin{array}{c}\text { FBG }(\mathrm{mmol} / \mathrm{L}) \\
(\mathrm{Mean} \pm \mathrm{SD})\end{array}$} & Percentage change \\
\hline & Day 1 & Day 15 & \\
\hline$B(n=6)$ & $5.70 \pm 0.39$ & $16.00 \pm 2.85$ & +190.38 \\
\hline$C(n=6)$ & $5.40 \pm 0.65 \mathrm{~ns}$ & $8.60 \pm 2.25 * * *$ & +43.55 \\
\hline$D(n=6)$ & $5.80 \pm 0.48 \mathrm{~ns}$ & $7.05 \pm 0.90 * * *$ & +28.86 \\
\hline
\end{tabular}




\section{Discussion}

The present study was carried out to compare the glucose lowering effect of ethanol extract of Psidium guajava (guava) leaves with Glibenclamide on experimentally induced diabetic rats. Diabetes was induced by alloxan. The dose and route of administration of alloxan monohydrate was selected from Andrade et al. and Kim et al. ${ }^{11,12}$ The blood glucose levels in animals were measured 72 hours after administration of alloxan which was done according to experiment of Etuk et al. ${ }^{13}$ In this study, intraperitonial (ip) administration of single dose of alloxan $(120 \mathrm{mg} / \mathrm{kg})$ increased blood glucose level significantly. Similar observations were reported by number of researchers. Ghosh et al. ${ }^{14}$ observed the condition of diabetes after 24 hours of intravenous injection of sterile, freshly prepared $1 \%$ alloxan monohydrate solution at a dose of $40 \mathrm{mg} / \mathrm{kg}$ in albino rats. Jeloder et al. ${ }^{15}$ in their experiment observed the effect of fenugreek, onion and garlic on blood glucose and histopathology of pancreas of diabetic rats, by inducing diabetes in 20 out of 25 adult male albino rats by intraperitonial injection of $185 \mathrm{mg} / \mathrm{kg}$ of alloxan. In the present study, the rise of blood glucose level in experimental diabetic rats was also very high.

The dose of Psidium guajava leaves $(100 \mathrm{mg} / \mathrm{kg}$ body weight), and duration used in this study was selected in keeping conformity with the dose and duration used in research work by Yesmin. ${ }^{7}$

The leaves of guava are rich in flavonoid, in particular, quercetin. Quercetin is the main flavonoid in guava leaves which contribute to its anti hyperglycemic effect. ${ }^{7}$ Flavonoid compounds act against diabetes mellitus either through their capacity to avoid glucose absorption or by improving glucose tolerance. ${ }^{16}$ The epicatechingallate, myricetin, quercetin, apigenin, epigallocatechin gallate, and epigallocatechin demonstrated a marked reduction in glucose absorption, when compared with control, by competitive inhibition of sodium dependent glucose transporter. ${ }^{17}$ In several studies it was found that flavonoids act directly on pancreatic beta cells leading to activation of the cAMP/PKA signaling cascade to exert an insulinotropic effect. ${ }^{8}$ As a result bioflavonoids are now a days regarded as promising and significantly attractive natural substance to enrich the current therapy options against diabetes.

It was observed that the ethanol extract of Psidium guajava leaves has glucose lowering effect in alloxan induced diabetic rats. It has the capability of reducing blood glucose level in diabetic rat as well as Glibenclamide.

The result suggests that the ethanol extract of Psidium guajava (EEPG) leaves may be useful anti diabetic agent in treatment of diabetes mellitus. The observation and results of the study provided a rationale for the use of Psidium guajava leaves in the development of a new drug for treatment of Diabetes mellitus. It is recommended that further studies should be carried out regarding pharmacokinetics, pharmacodynamics and toxicology of the ethanol extract of Psidium guajava leaves. It is suggested to measure plasma insulin level, HbA1C, liver glycogen level, lipid hydroperoxidation level and free radical in the tissues after treatment with ethanol extract of Psidium guajava leaves. Despite all these limitations, interpretation of the results obtained in this study was made carefully and cautiously.

\section{References}

1. N Haque, Salma U, Nurunnabi TR, Uddin MJ, Jahangir MFK, Islam SMZ, et al. Management of Type 2 Diabetes Mellitus by Lifestyle, Diet and Medicinal Plants. Pakistan Journal of Biological Sciences. 2011;14:13-24.

2. Roglic G, Unwin N, Bennet PH, Mather C, Tuomiletho J, Nag S, et al. The Burden of Morality Attributable to Diabetes: Realistic Estimate for the Year 2000. 2005;28:2130-35. 
3. Khan AKA, Mahtab H, Grant J, Stewart M, Ahmed T, Haq JA, editors. Diabetes Mellitus. 2nd ed. Dhaka: Diabetic Association of Bangladesh; 2007. p. 22-41.

4. Modak M, Dixit P, Londhe J, Ghaskadbi S, Devasagayam TPA. Indian Herbs and Herbal Drugs Used for the Treatment of Diabetes. J Clin Biochem Nutr. 2007;40:163-73.

5. Barbalho SM, Farinazzi-Machado FMV, Goulart RA, Brunnati ACS, Ottoboni AMMB, Nicolau CCT. Psidium guajava (guava): A Plant of Multipurpose Medicinal Applications. Med Aromat Plants. 2012;1:104. doi:10.4172/2167-0412.1000104.

6. Porwal V, Sing P, Gurjar D. A Comparative Study on Different Methods of Extraction from Guajava Leaves for Curing Various Health Problems. IJERA. 2012;2(6):490-96.

7. Yesmin N. Hypoglycemic Effect of Guava Leaves upon Alloxan Induced Diabetic Rats. Department of Pharmacology, Our Lady Fatima University, Philippines. 2009-2010. Power Point File. 2010 June 17.

8. Liu D, Zhen W, Yang Z, Carter JD, Si H, Reynolds KA. Genistein Acutely Stimulates Insulin Secretion in Pancreatic Beta-Cells through a Camp-Dependent Protein Kinase Pathway. Diabetes. 2006;55(4): 1043-50.

9. Gross GJ, Auchampach JA. Blockade of ATP Sensitive Potassium Channels Prevents Myocardial Preconditioning in Dogs. Journal Circ Res. 1992;84:973-79.

10. Kunte H, Schmidt S, Eliasziw M, del Zoppo GJ, Simrad J, M Masuhr, et al. Sulfonylureas Impove
Outcome in Patient with Type 2 Diabetes and Acute Ischemic Stroke. 2007;38(9):2526-30.

11. Andrade SI, Monslave, MCR, Pena JEDL, Polanco AC, Palomino MA, Velasco AF. Streptozotocin and Alloxan in Experimental Diabetes: Comparison of the Two Models in Rats. Acta Hischem Cytochem. 2000;33(3):201-208.

12. Kim JS, Ju JB, Choi CW, Kim SC. Hypoglycemic and Antihyperlipidemic Effect of Four Korean Medicinal Plants in Alloxan Induced Diabetic Rats. Am J Biochem Biotech: 2006;2(4):154-60.

13. Etuk EU, Muhammad BJ. Evidence Based Analysis of Chemical Method of Induction of Diabetes Mellitus in Experimental Rats. J Res Pharmachol Sci. 2010;1(2):139-42.

14. Ghosh R, Sharatchandra K, Rita S, Thokchom IS. Hypoglycemic Activity of Ficushispida (Bark) in Normal and Diabetic Albino Rats. Indian J Pharmachol. 2004;36(4):222-25.

15. Jeloder GA, Maleki M, Motadayen MH, Sirus S. Effect of Fenugreek, Onion and Garlic on Blood Glucose and Histopathology of Pancreas of Alloxan Induced Diabetic Rats. Ind J Med sci 2005;59(2):64-69.

16. Bhathena SJ, Velásquez MT. Beneficial Role of Dietary Phytoestrogens in Obesity and Diabetes. Am J Clin Nutr. 2002;76(6):1191-1201.

17. Shimizu M, Kobayashi Y, Suzuki M, Satsu H, Miyamoto Y. Regulation of Intestinal Glucose Transport by Tea Catechins. Bio Factors. 2000;13:61-65. 